\title{
(In)Essential Bordering: Canada, COVID, and Mobility
}

\author{
Audrey Macklin* \\ Centre for Criminology \& Sociolegal Studies and Faculty of Law, University of Toronto, Toronto, ON, Canada
}

The global migration of COVID-19 not only disrupted transborder movement. In many (if not most) states, statis, and closure became the default norm at and within borders. This, in turn, generated exceptions organized around an idea of "essential" entry. The category of "essential" was produced, revised, and represented through the interaction of pandemic-driven exigencies and nationally specific configurations of the legal, political, and economic forces in play. To understand how the admission into Canada of certain people was accepted as legally, economically and/or politically essential, one must take account of Canada's character as a settler society, its economic integration with the United States, and its growing dependence on migrant workers and international students to subsidize food production and higher education for nationals.

\section{OPEN ACCESS}

Edited by:

Jaya Ramji-Nogales,

Temple University, United States

Reviewed by:

Frédéric Mégret,

McGill University, Canada

Rebecca Hamlin,

University of Massachusetts Amherst,

United States

*Correspondence:

Audrey Macklin

audrey.macklin@utoronto.ca

Specialty section:

This article was submitted to

Migration and Society,

a section of the journal

Frontiers in Human Dynamics

Received: 24 September 2020 Accepted: 01 December 2020

Published: 23 December 2020

Citation:

Macklin A (2020) (In)Essential

Bordering: Canada, COVID, and Mobility. Front. Hum. Dyn. 2:609694.

doi: 10.3389/fhumd.2020.609694

\section{INTRODUCTION}

The cross-border movement of a virus threw into chaos the cross-border movement of everything and everyone else. The unprecedented conjuncture of border closure and domestic immobilization has disrupted conventional patterns of movement and mobility into and within Canada. The hierarchy of admissibility according to legal status and national origin has been jumbled. Consider that in summer 2020, cars on Canadian streets bearing US license plates were viewed with suspicion and hostility, prompting calls to Canada Border Services Agency (CBSA) to report the illicit presence of Americans.

This paper uses Canada as a case study to explore two features of COVID's impact on bordering. The first inquires into the relationship between the control of movement across borders and movement within borders. COVID makes this salient because of the drastic and unfamiliar restraints imposed on individual movement at the local and inter-provincial level. In Spheres of Justice, Walzer (1982) famously provided a normative defense of closed national borders by, inter alia, predicting that if national borders were open, sub-state and local communities would reactively erect barriers to entry in order to preserve the sense of communal membership. This world of a "thousand petty fortresses" was contrasted to a national territory characterized by unimpeded mobility. In other words, the maintenance of free movement within the state is underwritten by the presumption of closure of national borders. COVID-induced regulation both tracks and disrupts this model.

The second feature of Canada's pandemic migration regulation is the reconfiguration of the conventional priorities and preferences for non-citizen entry. Like other affluent countries, Canadian migration law facilitatex travel and migration by nationals from other states of the global north (and Australia/NZ), in contrast to nationals from the global south. Ideas about the desirable traveler and migrant are infused with ideas about class, race, religion, ability etc. 
This passport privilege has been temporarily displaced by a different hierarchy based less on "desirability" than immediate necessity. In Canada and elsewhere, pandemic rules have been organized around ideas about whose entry, which labor, and which interests are "essential." I offer a typology of "essential" that braids together economic, legal, and political elements. While this article is not comparative, I suspect that particular choices about who and what is "essential" might vary between states, and that these variations might link to different conceptions of migration, the nation, and national belonging. Canada is a settlersociety. It is built literally and discursively on a commitment to immigration that, in the first instance, displaced Indigenous people and consolidated colonial political power. It provided the demographic, economic, and social foundation upon which the state was assembled and continues to grow. Other states have a different migration history and trajectory, but all face similar challenges around COVID. It may be premature to theorize the impact of COVID on bordering while events are still unfolding, but one can begin the task of tilling the ground.

\section{THE UNEXCEPTIONAL BORDER}

A conventional metaphor for the border depicts it as a filter or screen that slows and halts the entry of some, while permitting and expediting the entry of others. In ordinary times, this image is juxtaposed against the situation within state territory, where movement is unimpeded and virtually unregulated. COVID has eroded this distinction between governance of movement at the border and inside the country. I do not anticipate that the changes wrought by COVID will become permanent, but what has changed irrevocably is the assumption of irrevocability.

As COVID traveled the world passport-free, a predictable reaction of states was to target for exclusion travelers from alleged source countries-first China, then Iran and Italy. We know this exclusion narrative well, replete with metaphors of foreign viruses infecting the body politic, and the deplorable enthusiasm with which some political leaders fomented and exploited it. The racist and stigmatizing effects of labeling COVID19 the "Chinese" or "Wuhan" virus" are made no less pernicious by their predictability.

Critics of these border closures rightly observed that they would likely fail to halt the spread of the virus, partly because these closures inevitably happen after the virus has already found its way in-the inverse problem of shutting the barn door after the horse has bolted. By around mid-March, it became evident that the virus was everywhere and could not be stopped, only slowed. At that moment, borders slammed shut more tightly and more pervasively than many of us had ever seen in our lifetimes. But this quantitative intensification of border control masked a shift in its qualitative character that was produced by a transformation in the governance of movement more generally.

Discriminating against "dangerous" foreigners from certain states-China, Italy, Iran-belongs to the banal work of racist border control in the Global North. It has a long and ignoble pedigree. Identifying foreigners as vectors of disease and degeneration in both physical and moral terms is a familiar trope. One need not reach far back to recall, for example, the "homosexual Haitian drug user" as the villain in the HIV/AIDs origin story. "Xenophobia: COVID Edition" seems to this observer like a variation on a familiar theme ${ }^{1}$. But this endeavor of excluding the foreign menace was superseded by the project of halting movement as such, of which cross-border movement was only one type. Once it was apparent that stopping the virus was not viable and the goal shifted to slowing its spread (pending a vaccine), any and all movement became undesirable. In this context, borders mark critical jurisdictional breaks. Canada does not govern the territory of other states, and the actions and inactions of those other states in managing the pandemic become a source of risk embodied in individual foreign travelers. But it was not the conduct or character of border-crossers themselves that was at issue.

At the same time, the pandemic precipitated unprecedented restraints on movement within the territory of the Canadian state, and this applied to citizens and non-citizens alike. From the individual body, to the household, to municipalities, to provinces and, finally, to the state, the universal object of governance became the arrest of human movement. Each person was a potential vector and victim of disease, and controlling mobility preoccupied every jurisdiction at every scale of governance. With policing techniques ranging from appeals to solidarity to threats of criminal sanction, people were told to stay home, to stay away from one another, to stay put. In ordinary times, the default position for state borders is closure, subject to exception; within the state, the default is free movement, subject to exception. In Canada, s. 6 of the Canadian Charter of Rights and Freedoms not only protects the right of citizens to enter, but the free movement of citizens and permanent residents throughout Canada. Yet, under COVID, it was all stasis, all the time, everywhere, for everyone. Movement was policed by state actors, by neighbors, via cell phone technology and otherwise; inessential movement was subject to opprobrium, or worse. Borders between provinces that hitherto only functioned to mark the transition between sub-state jurisdictions were activated to impede interprovincial or inter-regional movement. A Newfoundland law barring interprovincial travel withstood constitutional challenge, though it is under appeal (Taylor, 2020).

Within this regime of immobilization within the state, where citizenship is less relevant, border control appears less distinctive, and more like one node in a matrix of mechanisms aimed at halting the circulation of people. The technology of border control is purpose-designed to maximize coercion and minimize accountability, and one should not trivialize its specificity and violence. Having said that, it is worth noting how border control under COVID was interpolated into an infrastructure of mobility control that was not primarily about migration. It was primarily about slowing the spread of the virus, the same objective shared by a suite of domestic measures, including quarantine, lockdown, social distancing rules, internal travel restrictions, mobile app

\footnotetext{
${ }^{1}$ For example, Canada adopted explicitly racist entry policies against Chinese migrants from 1885 to 1946, and covertly (and more effective) racist policies against Japanese and South Asian migrants from the early twentieth to midtwentieth century. See generally, Aiken (2007).
} 
contact tracing, and so on. In this sense, the border's function in arresting movement was no longer unique. That is new. (That some employers would use their power to restrict the mobility of migrant workers even more harshly is not new).

Thanks to COVID, a vision of Walzer's world of a thousand petty fortresses came into view, with provinces erecting barriers to non-residents, including former residents. People in rural areas grumbled loudly about city dwellers "escaping" to their cottages or chalets and bringing COVID with them. Fragile northern communities (especially Indigenous) tried to protect themselves by denying access to people from outside the region. But Walzer imagined this as a reaction to [more] open borders. That is not the explanation for the sub-national restraint of movement under COVID. There is no trade-off between closure at one scale and openness at another. Here, state sovereignty is not manifested by preventing entry, but by controlling, confining, and surveilling movement, of which cross-border movement is only the exemplar. We cannot know now, and perhaps will not know for a long time, the durability, shape, and the trajectory of states' newly revived and amplified will and capacity to regulate movement that begins not with crossing a border between two states, but with crossing a threshold between abode and outdoors. In my view, the measures adopted since COVID undermine the very idea of mobility as free movement, and tilt toward a vision of mobility as permitted movement.

\section{ESSENTIAL CONNECTIONS}

\section{Essential Movement}

Even in a pandemic, borders cannot be hermetically sealed. While the pandemic obviously restricted entry, it also reconfigured the basis for admission in revealing ways. Unlike many other states, the Canadian government did not respond to the pandemic by declaring a national emergency and invoking the powers contained in the Emergencies Act. Under Canada's federal system, international border control falls under federal jurisdiction, and Emergency Orders issued and renewed monthly by Cabinet under the authority of s. 58 of the Quarantine Act regulated cross-border movement, overriding or otherwise altering existing provisions of the Immigration and Refugee Protection Act.

The term "essential" became the stamp on the notional permit that validates movement. Technically, the Emergency Orders do not positively authorize "essential" border crossing. Instead, they prohibit entry for "optional" or "discretionary" purposes. The residue that remains is travel for an "essential purpose."

Who or what is essential, and why? For present purposes, I will detach the label "essential" from "services," "work" or "worker" and instead consider more broadly the reasons that give shape and content to the category "essential," which in turn signifies an exception to the default of stasis and exclusion. I propose that entry might usefully be classified as legally essential, politically essential, or economically essential. The legal dimension captures constitutional, international, or legislative provisions that constrain the power of the state to exclude. While it is true that most laws create exceptions for emergencies of various sorts, the existence of an initial legal obligation can still exert significant force over policy choices.
Entry is economically essential to a state in respect of those workers who transport otherwise unavailable goods or who provide vital and otherwise unavailable forms of labor, such as health care, sanitation, public transportation, and food production and distribution. However, as the Canadian case shows, workers are not the only non-citizens considered essential to the Canadian economy.

The category of politically essential entry necessarily overlaps with the other two, and is necessarily contested and contingent. Claims that entry is legally or economically essential will be leveraged by interested parties (employers, institutions etc.) to persuade politicians to create an exception to the default of closure and exclusion. But the political impetus may also be generated from successful public appeals to moral, social, or pragmatic considerations.

These proposed categories of essential entry are neither mutually exclusive, nor static. They simply provide a rough schema for organizing and comparing the diverse responses of various states to the challenges of COVID and transborder movement.

\section{US and Everywhere Else}

Canada's only land border is with the United States. The CanadaUS border is not only a barrier, but also a suture stitching together two political units into a deeply interdependent economic, social, and political relationship (Salter, 2012). Early on, it became obvious that the neither the US federal government, nor most state governments, would or could act quickly to contain the spread of COVID. Inevitably, the per capita infection and fatality rates in the US would (and did) soar relative to Canada. Restricting the flow of entrants from the United States was both vital from a public health perspective and potentially devastating to the Canadian economy. This tension between sovereign self-interest and unequal economic power plays out across a range the full range of Canada-US relations, and the pandemic provides another site for observing its effect on migration and border management.

Each month since March 2020, Cabinet has renewed not one, but two Emergency Orders under the Quarantine Act that govern cross-border movement. One is for foreign nationals entering Canada from the United States. The other is for foreign nationals entering from all other countries. The salient difference between the two Orders is the default starting point. Foreign nationals from the United States are prohibited unless their entry is not for an optional or discretionary purpose. Foreign nationals from elsewhere are prohibited unless they come within a list of designated exceptions, and if their entry is not for an optional or discretionary purpose. A non-exhaustive list of examples of discretionary or optional travel includes "tourism, recreation, and entertainment." Until October 2020, internationals students arriving directly from the United States were admissible if they possessed student permits issued anytime; international students arriving from anywhere else had to possess student permits issued before 18 March 2020. As discussed below, the government amended these rules in mid-October 2020.

The reason for the preferential treatment of the United States is straightforward: The United States is the only country with 
whom Canada shares a land border. North American economic integration makes the cross-border traffic of goods (including food and health equipment) from the United States vital to Canadians. US truckers become essential workers to Canada, and the Emergency Order enables them to traverse the border as visitors (they are also exempt from the quarantine requirement). Indeed, the same quarantine exemption applies to hundreds of Canadian nurses living in the Windsor, Ontario area who cross the border daily to work in Detroit hospitals and return home to Windsor.

Travel to Canada for tourism and business travel are prohibited as optional and discretionary, although special permits are granted for overland transit through Canada from continental United States and Alaska, and vice versa. Well-publicized stories of Americans who assured CBSA that they were transiting through Canada, but who were actually vacationing in Canada, stoked a certain degree of suspicion and animosity directed at drivers of cars with US license plates. While mocking Americans is something of a national pastime in Canada, there was something undeniably novel about casting the white, affluent, middle-aged American tourist in the role of foreign scofflaw and vector of contagion. Even more troubling, however, were revelations that senior Canadian officials authorized entry of several US business executives to Canada during the pandemic with no requirement to quarantine (Gatehouse, 2020).

\section{CITIZENS AND PERMANENT RESIDENTS}

As states moved to close borders in response to the pandemic in early 2020, Canadian citizens outside Canada remained free to re-enter, subject to a 14-day quarantine period. Indeed, the Prime Minister of Canada repeatedly urged Canadians abroad to return to Canada as soon as possible. Since the right of citizens to enter Canada is constitutionally protected under section 6 of the Canadian Charter of Rights and Freedoms, as well as international law, one might understand access by citizens to Canadian territory as legally essential. But it bears noting that citizens who exhibit any symptoms of COVID illness can be refused boarding by airline carriers, rendering them de facto excluded. Here, bio-status trumps citizenship-status when citizens travel by air, which they must do to reach Canada from anywhere but the United States.

Why did the Prime Minister exhort Canadians to return? One might read this as a romantic appeal to the Canadian diaspora: in times of crisis, one can and should return to the protective embrace of the homeland (Mégret, 2020). Of course, patriotism can be mobilized toward a variety of ends. The Chinese government blocked Canadian-Chinese dual citizens from leaving China (often with Canadian family members) and traveling to Canada. At the same time, the Chinese government actively discouraged thousands of Chinese international students attending Canadian from returning to China, ostensibly to minimize any risk of reintroducing COVID into China. It seems that Chinese citizens in China behave patriotically by remaining in China, while those abroad express their patriotism by not returning home to China.
In general, the call to "come home" tracked the predictable eruption of xenophobia directed at actual or perceived "foreigners" (Purohit and Mukherjee, 2020; Stevens, 2020). The familiar story is that the non-citizen and the racialized other (in this case, people with Asian features) always teeter at the edge of outsider status, and an outsider is always vulnerable when bad things happen and people look for someone to blame. Around the world, anti-Asian racism, and scapegoating of migrants and foreigners escalated.

From a purely pragmatic perspective, the Canadian Prime Minister's appeal to citizens abroad also anticipated the imminent global shutdown of international travel. The government wished to avoid the prospect of thousands of Canadian citizens stranded abroad and calling on the Canadian government to repatriate them. And even though the Canadian government insistently (though quietly) declares that consular assistance in the form of repatriation is dispensed as a matter of discretion, not entitlement, Canadians continue to expect it. The political cost of refusing to repatriate Canadians would be enormous, so better to do so before the logistical and financial cost escalated even further.

Permanent residents of Canada do not enjoy a constitutional right to (re)enter Canada, but they do enjoy a statutory right under s. 19(2) of the Immigration and Refugee Protection Act to enter Canada. Permanent residents must physically reside in Canada for at least 6 months a year to maintain their status. A purely statutory right can be abridged more easily than a constitutional right, but in any case, the orders issued under the Quarantine Act preserved permanent residents' ability to enter Canada on the same terms as citizens. This was true of most countries in the Global North, who recognized that exclusion of permanent residents would have been politically untenable. The Canadian government also included many permanent residents in repatriation flights (Government of Canada, 2020f).

Unsurprisingly, the government continues to discourage Canadians from non-essential travel outside Canada (Government of Canada, 2020f). In the early days of the pandemic, many Canadians (with the support of some provincial premiers) disregarded the advice of public health officials not to travel south for spring break vacations, and it appears that this accelerated the spread of COVID in Canada. Thousands of retired Canadians spend the winter in Florida, Arizona, and California. In October 2020, Prime Minister Trudeau cautioned against traveling to the US but added,

"If someone chooses to travel, we're not going to keep them imprisoned in Canada. There is freedom of movement in this country. [But] they have to recognize that they're putting themselves at risk". They're putting loved ones at risk (Muggeridge, 2020).

In light of the various restraints on mobility within Canada, Prime Minister Trudeau's invocation of freedom of movement is striking, if not ironic.

\section{FOREIGN NATIONALS IN CANADA}

\section{Workers}

Canadian immigration law defines foreign nationals as noncitizens who are not permanent residents. When the pandemic 
struck, some foreign nationals who had resided in Canada for extended periods on renewable work permits happened to be temporarily abroad. Their legal entitlement to enter is even more conditional and precarious under immigration law than permanent residents, but the government ultimately permitted them to return. To understand why, it is worth noting that over the past 15 years, Canadian immigration policy has reduced the proportion of "high" skill economic immigrants admitted directly as permanent residents in favor of two-step immigration schemes that require migrants to undergo a period of temporary status before qualifying for permanent residence. Thousands of foreign nationals live and work in Canada more or less continuously for years (often with families) on a succession of temporary work permits. Many temporary work permit holders are indistinguishable from those admitted as permanent residents in the economic class. But legally, the line between temporary and permanent resident status means that temporary residents' continuous, long-term physical presence in Canada is inconsequential. During COVID, however, prior presence sufficed for purposes of admission (Government of Canada, 2020c).

\section{International Students}

All major Canadian universities are publicly funded, but governments cover a decreasing proportion of actual costs. Historically, the education of international students was framed as a form of quasi-international development assistance, in which students from the Global South would acquire a university education in Canada that they would carry back and apply in their countries of origin. By the turn of the twenty-first century, this neo-colonial model of international students as aid recipients evolved into a neo-liberal model of international students as revenue stream. Programs that enable some international students to obtain post-graduation work permits incentivize international students to choose Canada as a destination in the hopes of finding a pathway to permanent immigration. Today, Canadian universities depend heavily on tuition fees charged to international students; international student tuition across Canadian universities average 4.5 times the fees charged to domestic students (Statistics Canada, 2020). Even as the pandemic pushed post-secondary institutions to facilitate online course instruction for the vast majority of programs, universities were anxious to maintain international student enrolment. They worried that international students would balk at paying exorbitant tuition fees without the benefit of actually living in Canada. Thus, universities lobbied the federal government to ensure that international students who were willing to leave their home countries could still travel and live in Canada-even if they studied online after arrival.

Universities found themselves in a quandary: The physical presence of international students is economically essential to Canadian post-secondary institutions. But universities' own efforts to manage the pandemic by going online refuted the claim that physical presence is essential to fulfillment of universities' pedagogical mission. The economic imperative to enable international students to enter Canada thus collided with the bar on entry for "discretionary" or "optional" purposes.
Although the federal government allowed online courses to "count" for purposes of activating a study permit, this did not resolve the problem of entry.

Universities only partially succeeded in enabling international students to enter in time for the launch of the academic term in September 2020. As with holders of temporary work permits, government policy drew on past residence as a criterion for designating entry as essential. Returning international students able to prove that they had already lived in Canada could enter. This did not address the situation of first-year international students, unless their university furnished a supporting letter from the university attesting that "the program requires inperson attendance ... once the [university] is able to resume classroom operations." The university was also required to "indicate a target start date for courses that require the student to be in Canada" (Government of Canada, 2020e). International students arriving directly from the United States could hold student permits issued anytime; international students arriving from anywhere else could only hold student permits issued before 18 March 2020. But even with a study permit in hand, actual admission remained subject to CBSA officers' exercise of discretion at the port of entry. This meant that students could not confidently predict whether they would be admitted until they actually traveled to Canada.

In mid-October 2020, the federal government announced a new program to enable international students to study in Canada. Henceforth, provincial governments would certify individual Canadian universities with an approved "COVID readiness plan" as Designated Learning Institutions (DLI). International students possessing study permits for DLIs could enter, and would follow the quarantine protocol arranged by the university (Government of Canada, 2020h). This model was the product of assiduous negotiations with government by Canadian postsecondary institutions. Although it arrived too late for the start of the academic year, it enables universities to continue offering the "in-Canada" experience to international students for whom online study from the country of origin was not worth the price of tuition.

\section{FAMILY MEMBERS}

Over $20 \%$ of Canada's population was born abroad. Immigration is written into Canada's nation-building narrative as a settler society; historically, family-based migration was considered integral to social and demographic. Untold numbers of Canadian citizens, as well as permanent and foreign nationals in Canada, have close kin who are foreign nationals. Even though noncitizens have no currency in the political marketplace, they are virtually represented by the millions naturalized citizens and descendants of immigrants. The admission of foreign national family members of people who reside in Canada emerged as a contentious issue early in the pandemic. Foreign national family members had no legal or economic argument in favor of admission, but the government eventually relented. The admission of foreign national family members of those who had made Canada home became politically essential, even if not legally required. 
Emergency orders under the Quarantine Act prohibit entry for optional or discretionary purposes, and specifically list tourism, recreation, and entertainment as examples. This leaves considerable interpretative latitude in the hands of CBSA officials standing at the border. The government's initial position on non-optional/non-discretionary exceptions to border restrictions was that " $[t]$ here are no exemptions to border restrictions for compassionate reasons, such as visiting a critically ill loved one or attending a funeral" (Government of Canada, 2020f, p. 5). Early on, however, the government declared an exemption for immediate family members (intimate partners and dependent children) of citizens and permanent residents. These foreign nationals could be admitted as visitors if it was "for an essential purpose."

Over the course of several months, media accounts abounded of foreign national spouses denied entry to attend the birth of their child, adult children unable to visit or care for their ailing, elderly parents, and long-term long-distance couples refused permission to see one another (Bureau, 2020a,b). Other states wrestled with the same issue (Dutch News, 2020). In each of the Canadian cases, CBSA officers determined that the foreign national did not qualify as an immediate family member and/or that the purpose of travel was inessential. In some cases, CBSA officers threatened to issue a 1-year ban if the foreign national did not surrender their attempt to enter Canada (Harris, 2020).

Ad-hoc advocacy sprung up across Canada to press for a wider definition of immediate family, and for recognition of family reunification as intrinsically essential. The "Faces for Advocacy" group set up a social media presence under the slogan "Family Reunification, Not Open Borders," and engaged in a media campaign, and government lobbying (Faces of Advocacy, 2020). In a subsequent order under the Quarantine Act, "immediate family" was broadened to include parents and step-parents and adult children of citizens and permanent residents (Government of Canada, 2020b). The government also removed the requirement for foreign national family members to establish the essential purpose of their travel, thereby reducing border officials' negative discretion; in effect, family reunification as such was deemed essential for those who fell within the definition of family, who were reuniting in Canada with a citizen or permanent resident, and who would be staying beyond the mandatory 14-day quarantine period (Government of Canada, $2020 \mathrm{a}, \mathrm{d})$. Immediate family members of temporary residents were required to obtain an advance authorization letter from Immigration, Refugees and Citizenship Canada, which they would present at the port of entry. CBSA border officials retain residual discretion to reject them at the port of entry, even with the letter. An indirect indication of how CBSA border officials had been wielding their discretion is provided by a policy guideline clarifying that non-discretionary or non-optional travel could indeed include a "foreign national coming for the birth of their own child to another foreign national with temporary resident status" (Government of Canada, 2020a).

While the Canadian government recognized admission of some family members as politically essential from the outset, successful advocacy reconfigured family reunification as intrinsically essential, such that family members did not have to demonstrate why reunification was essential. It also expanded the ambit of who counted as "family" in the pandemic. Importantly, media attention appeared to play an important role, and many profiles of separated family members featured people who were not habitually the subject of restrictive and arbitrary border enforcement, or politically active on migration issues. Indeed, the slogan "Family Reunification, Not Open Borders," underscores the conservatism of the campaign.

\section{SEASONAL AGRICULTURAL WORKERS}

Canada operates a Seasonal Agricultural Worker Program (SAWP) via bilateral agreements between the governments of Canada as destination state, and Mexico and Jamaica as sending states. Through this program, the government subsidizes the agricultural employers' labor costs by furnishing migrant workers who work in greenhouses, orchards and other industrial agriculture operations for wages and working conditions that Canadians will not accept. Privatized variations on this model supply Canadian agricultural businesses with temporary migrant workers from Guatemala, Philippines, Indonesia and elsewhere. Most return year after year on work permits that tie them to particular employers for a stipulated duration of up to 10 months. The workers can never transition to permanent residence, and must perform the annual ritual of returning "home" for some period of time in order to affirm their legal designation as temporary.

The work requires long hours of hard physical labor and is poorly paid. Respect for occupational health, safety and employment standards by employers is uneven, and exploitative practices by unscrupulous employers are endemic and welldocumented. The demand for the labor may or may not be temporary, but the visa is restricted in duration in order to keep the workers temporary. Because of their precarious immigration status (accompanied by the ubiquitous threat of deportation), they experience wage-theft, over-work, unhealthy and dangerous working conditions, overcrowded and inadequate shelter, poor sanitation, and restricted access to food, health care, and liberty (Migrant Workers Alliance for Change, 2020).

In the initial iteration of the pandemic travel restrictions, temporary workers who did not reside in Canada were barred from entry. This excluded seasonal agricultural workers because, as noted above, the requirement to return home annually meant that each entry would be based on a new temporary work permit precisely so they could not claim to reside in Canada. Their exclusion under COVID rekindled a familiar discussion about migrant labor. Although frequently denigrated as "unskilled" and thus undeserving of permanent residence, employers now emphasized the skill, experience, and efficiency of seasonal agricultural workers. They reiterated the refrain that Canadians-even in the face of unprecedented unemployment rates-could not and would not do the arduous work. And so, in order to sustain the food supply in Canada, the entry of seasonal agricultural workers was facilitated as an exception because their admission was economically essential to Canada. 
But upgrading the work to essential did not make the workers essential. Rather, it exposed the extent to which migrant agricultural labor is essential because the workers themselves are dispensable. This is not a paradox: slave labor is essential to a slave economy but, and because, enslaved people have no intrinsic worth in that economy.

Migrant workers were screened for COVID before departure, and employers pledged to honor the 14-day quarantine period, ensure housing and working conditions that respected social distancing requirements, and to otherwise respect and protect workers' health. The Jamaican government, recognizing the remittances by seasonal agricultural workers as economically essential, a report that the Jamaican government was requiring Canada-bound workers to sign a waiver of any liability for contracting COVID while employed in Canada (Mojtehedzadeh, 2020). The dependence of sending states on remittances, their competitive relationship with other sending states, and their weakness relative to destination states, often result in tepid protection and advocacy by sending states for overseas workers.

Consistent with pre-COVID patterns of employer misconduct, many Canadian employers did not respect the quarantine period, coerced employees into working immediately alongside local workers (who did not live on site and circulated freely), did not provide them with adequate housing, personal protective equipment or means of social distancing and, in some cases, physically confined them to the property. Non-compliant workers were threatened with repatriation. Government inspectors-who refrained from entering workplaces because of the risk-conducted virtual inspections in which they relied on employer reports.

COVID outbreaks on farms and greenhouse operations erupted almost immediately. In surrounding communities and commercial establishments, migrant workers were stigmatized and even refused service (Hennebry et al., 2020). For the first 6 months of the pandemic, the agricultural industry (including meat packing plants) and privately-operated long-term care facilities were responsible for the overwhelming majority of positive cases and deaths in Canada. In each sphere, the common denominator is a work force that is disproportionately racialized and low-paid, and populated by migrants who lack secure migration status. A key finding of a study of the differential impact of COVID on non-citizen and racialized people in Ontario (Canada's largest province) found that, as of June 2020, "Although immigrants, refugees and other newcomers make up just over $25 \%$ of the Ontario population, they accounted for $43.5 \%$ of all COVID-19 cases" (Guttmann et al., 2020). The study did not include seasonal agricultural workers, which would have significantly increased the proportion of non-citizen COVID cases.

Civil society organizations focused on migrant and refugee rights continue document conditions facing precarious migrants and refugees during the pandemic, using mainstream and social media, as well as public protest, to advance long-standing demands to issue migrant workers (across a range of occupations) access to permanent resident status (Migrant Workers Alliance for Change, 2020). In one well-publicized case, a migrant farm worker was fired for allegedly speaking to media after he tested positive and a roommate died from COVID-19. The agri-business employed hundreds of workers under Canada's seasonable agricultural program. The employer failed to provide safe, clean and well-supplied accommodation for workers. By June 2020, over 190 workers tested positive. With support from a migrant rights organization, he was able to resist the employer's attempt to summarily deport him. He filed a complaint against the employer for engaging in reprisal against the worker. In early November, the Ontario Labor Relations Board ruled in favor of the worker, awarding him lost wages and damages (GabrielFlores, 2020).

Migrant worker organizations have drawn attention to the essential services these workers provide to a Canadian economy in crisis. They face a heightened risk of infection, illness and death because of the nature of the work they perform, compounded by employer disregard for their health and safety. With the exception described below regarding some asylum seekers, the government has deflected the issue and, instead, provided tens of millions of dollars to employers to encourage them to undertake the protective measures they had already pledged and failed to provide.

\section{ASYLUM SEEKERS AND REFUGEES}

At the bottom of all hierarchies of legal migration are refugees and asylum seekers. The admission of people in need of refugee protection is not politically or economically essential to Canada. Refugee resettlement is not legally required, and Canada halted resettlement in March 2020. It resumed slowly in late August, but it is clear that Canada will not meet its resettlement targets for 2020 at the current pace.

Canada's obligations toward asylum seekers qualify their admission as legally essential under a proper interpretation of Canada's obligations under the UN Refugee Convention (United Nations High Commissioner for Refugees, 2020), but it is undeniable that Canada (like most other states) seeks to evade those obligations. In a separate contribution, Rehaag et al. have described how Canada leveraged the pandemic to advance its goal of preventing asylum seekers from reaching Canada and claiming refugee protection. In a depressing and distinctive display of Canadian-ness, the government has classified the entry of NHL hockey teams (and their entourages) as essential, but not the entry of asylum seekers (Mohammed, 2020; Rehaag, 2020).

In July 2020, the Federal Court of Canada ruled that the Canada-US Safe Third Country Agreement (STCA) violates the Canadian Charter of Rights and Freedoms, based on the treatment to which asylum seekers are subject when returned to the United States under the STCA (Canadian Council for Refugees, 2020). The government is appealing the decision, has obtained a court order to retain the STCA in place pending the outcome of an appeal scheduled for early 2021, and the border remains closed to refugee claimants who do not fall within STCA exceptions. Those who are apprehended while crossing irregularly are pushed back to the United States.

Against this generally dismal landscape for refugees, one surprising development stands out. When the pandemic 
measures began, refugee and migration advocates launched a campaign to urge the federal government to provide access to permanent residence for front-line "essential workers" with precarious immigration status, including seasonal agricultural workers, other migrant workers, and refugee claimants. The Black Lives Matter uprising amplified the racialized character of the migrant worker population, and the impact of the pandemic on expressions of racism and xenophobia. Activists' calls to action were backed by evidence about the treatment of seasonal agricultural workers and temporary workers in meat packing plants. Front line workers in long-term care facilities also received considerable attention, especially in Quebec. Many among them were Haitian and African refugee claimants who had entered Canada irregularly from the United States post2016 (because the aforementioned STCA precluded them from entering through regular means) at a Quebec location known as Roxham Road. They had long been vilified as "illegal" immigrants in various quarters, including the Quebec provincial government, which had promoted various anti-Muslim and anti-immigrant policies since its election. But here they were, risking their health by providing services in nursing care, security, janitorial work, and food preparation.

In mid-August 2020, the federal government announced that refugee claimants working in the health sector in direct contact with patients would be granted direct access to permanent resident status (Government of Canada, 2020g) The federal immigration minister praised these refugee claimants for demonstrating "a uniquely Canadian quality in that they were looking out for others" (Kestler-D'Amours, 2020). There was, of course, a certain irony to rewarding refugee claimants for their enactment of "Canadian-ness," which they performed by doing work that Canadians would not do. But more significant was the exclusion of other services that were also deemed essential, which also exposed workers to heightened risk of infection, but which did not involve direct contact with the sick or elderly. Inside health care facilities, these included security, cleaning, and food preparation. Workers in other sectors, especially in agriculture, also faced heightened risks that were not inherent to the work (unlike health care), but largely attributable to employer failure to ensure safe working and living conditions. Additionally, precarious migrant workers who were not refugee claimants remain ineligible. A journalist estimated that the proposed measure would probably benefit no more than a thousand people. It emerged soon after the program announcement that while the federal government and other provinces were open to a wider scope of eligibility, at least for refugee claimants in the health sector, the Quebec government strongly opposed it (Gruda, 2020).

This exceptional initiative for refugee claimants appeals to the logic of deservingness and "earned" citizenship: non-citizens may be put on a path to citizenship as a reward for extraordinary sacrifice to the nation. A similar premise underwrote US President Obama's DACA program, whereby prosecution for irregular presence was extended to people without legal status who served in the US military or attended post-secondary education. The Canadian program's limitation to direct provision of health care, and the ineligibility of precarious workers who are not refugee claimants, both invite deeper reflection about the particular confluence of events and discourses that produced it. This unprecedented offer of permanent resident status for refugee claimants is both welcomed for those it includes, and contested as arbitrarily restrictive for those it excludes. In December 2020, four months after the initial announcement, the government opened the application process. The scope of the program remains confined to a subset of eligible refugee claimants who arrived before 18 March 2020 and who work in direct provision of health care (Pilon-Larose, 2020).

\section{CONCLUSION}

The global migration of COVID-19 not only disrupted transborder movement. In many (perhaps most) states, stasis and closure became the default norm at and within borders. It is too early to predict or theorize the future of mobility as free (vs. permitted) movement in an era of surveillance, internal borders, and lock-downs.

With respect to transborder movement, pandemic restrictions have in turn, generated exceptions organized around a conception of "essential" that was produced, revised, and represented through the interaction of pandemic-driven exigencies and nationally specific articulations of the legal, political, and economic constraints in play. It would be imprudent to suggest that these have permanently altered conventional migration and citizenship hierarchies. Yet, the pandemic has temporarily inverted conventional hierarchies of who (or whose labor) is essential enough to expose the status quo ante to greater critical scrutiny.

To understand how the admission of certain people to Canada was accepted as legally, economically and/or politically essential, one must take account of Canada's character as a "country of immigration," and its contribution to expanding grounds for admission of family members. Canada's economic integration with the United States explains its preferential treatment of entry from that country (despite the hazards posed by US governance of the pandemic). The exposure of Canada's dependence on migrant workers to subsidize food production and to deliver critical services counters the settler-society tendency to promote permanent immigration and settlement. It has also dampened anti-immigrant sentiment, as Canadians recognize the vital contribution of those admitted on a temporary basis.

If one describes Canadian policy on COVID admissions as a circle of inclusion, the government has drawn the circle around citizens, permanent residents, and foreign nationals who can demonstrate prior physical presence of some duration in Canada. In other words, the circle is drawn around functional rather than formal residence. Normally, formal temporary status prevails over functional residence under immigration law. One can reside in Canada continuously for years and yet remain permanently "temporary" because one holds only a temporary visa. Under COVID, the ethical significance of the fact that a student or worker actually lives in Canada-even if their status is "temporary"-has been validated in a way that it normally is not. The work performed by temporary foreign workers, so often 
deprecated as "unskilled" or misrepresented as "seasonal," has been newly valorized during COVID. The acknowledgment that the definition of family (essentially parents and children) used for ordinary immigration purposes was too narrow to address the urgent need for family members to connect with those residing in Canada during COVID was also noteworthy. Refugees, however, were left behind.

Each autumn, the Minister of Immigration, Refugees and Citizenship announces projected levels of immigration for the next year. On 30 October 2020, the federal government announced its plan to increase admissions over the next 3 years to compensate for the shortfall caused by the pandemic and facilitate economic recovery and future growth (Government of Canada, 2020i). The messaging is positive about immigration at a moment when many states have doubled down on xenophobia and exclusion, and that is remarkable in itself. The critical question is whether the insights gained through COVID, which carry with them profound potential for transforming migration policy, will survive the pandemic.

Each state has its own set of factors that combine to determine whose entry and what kind of labor is legally, economically and politically essential during the COVID-19 pandemic. But beyond these pragmatic considerations lie conceptions of

\section{REFERENCES}

Aiken, S. (2007). "From Slavery to Expulsion: Racism, Canadian Immigration Law and the Unfulfilled Promise of Modern Constitutionalism," in Interrogating Race and Racism, ed Vijay Agnew (Toronto, ON: University of Toronto Press), 55-111.

Bureau, B. (2020a). Turned away at border, pregnant couple stranded in New York's coronavirus zone. 7 May 2020. CBC News Online. Available online at: https://www.cbc.ca/news/canada/ottawa/turned-away-at-borderpregnant-couple-1.5538669 (accessed September 15, 2020).

Bureau, B. (2020b). Internal documents show CBSA scenarios to decide who gets across the border - and who doesn't. 2 June 2020. CBC News Online. Available online at: https://www.cbc.ca/news/canada/ottawa/cbsa-documentoutlines-scenarios-who-crosses-border-1.5594684 (accessed September $15,2020)$.

Canadian Council for Refugees (2020). Canada, 2020 FC 770. Available online at: https://decisions.fct-cf.gc.ca/fc-cf/decisions/en/item/482757/index. do? $\mathrm{q}=$ safe $\$+\$$ third $\$+\$$ country (accessed September 15, 2020).

Dutch News (2020, July 17). Dutch government backs down over 'sweetheart visas' for long-distance couples. Dutch News. Available online at: https:// www.dutchnews.nl/news/2020/07/dutch-government-backs-down-oversweetheart-visas-for-long-distance-couples/ (accessed August 21, 2020).

Faces of Advocacy (2020). Facebook. Available online at: https://www.facebook. com/facesofadvocacy (accessed 15 November 2020).

Gabriel-Flores (2020). Gabriel-Flores v. Scotlynn Sweetpac Growers Inc. Ontario Labour Relations Board Case No. 0987-20-UR.

Gatehouse, J. (2020). UPS executive granted special ministerial exemption from Canada's COVID-19 quarantine. CBC News Online. Available online at: https://www.cbc.ca/news/canada/ups-executive-quarantine-exemption- 1 . 5780753 (accessed December 12, 2020)

Government of Canada (2020a). Non-Optional and Non-Discretionary Travel: COVID-19 Program Delivery. Available online at: https://www. canada.ca/en/immigration-refugees-citizenship/corporate/publicationsmanuals/operational-bulletins-manuals/service-delivery/coronavirus/travelrestrictions/non-optional-non-discretionary.html\#ex (accessed August 21, 2020). the nation and identity, and broader social attitudes toward immigration that surely matter. These may best be revealed and appreciated through comparative analysis. By offering Canada as a case study, I hope to open the possibility for comparison between states.

\section{AUTHOR CONTRIBUTIONS}

The author confirms being the sole contributor of this work and has approved it for publication.

\section{FUNDING}

This work was supported by part of a COVID19 Research Topic. This article was fully waived. The author thanks the Pierre Elliott Trudeau Foundation and the Canadian Institute for Advanced Research for generously supporting the author's research.

\section{ACKNOWLEDGMENTS}

The author thanks the reviewers and Catherine Dauvergne for excellent and constructive comments, and Jona Zyfi for superb research assistance.

Government of Canada (2020b). Travel Restriction Measures: COVID-19 Program Delivery. Available online at: https://www.canada.ca/en/immigration-refugeescitizenship/corporate/publications-manuals/operational-bulletins-manuals/ service-delivery/coronavirus/travel-restrictions.html\#immediate-familymembers (accessed August 21, 2020).

Government of Canada (2020c). Coronavirus Disease (COVID-19): Who Can Travel to Canada-Citizens, Permanent Residents, Foreign Nationals and Refugees. Available online at: https://www.canada.ca/en/immigration-refugeescitizenship/services/coronavirus-covid19/travel-restrictions-exemptions.html (accessed August 21, 2020).

Government of Canada (2020d). Orders in Council PC 2020-0565: Minimizing the Risk of Exposure to COVID-19 in Canada Order (Prohibition of Entry into Canada from the United States). Available online at: https://orders-in-council. canada.ca/attachment.php?attach=39536\&lang=en (accessed August 21, 2020).

Government of Canada (2020e). Corona Virus Disease (COVID-19): International Students. Available online at: https://www.canada.ca/en/immigrationrefugees-citizenship/services/coronavirus-covid19/students.html\#travel (accessed August 21, 2020).

Government of Canada (2020f). Coronavirus Disease (COVID-19): Travel Restrictions, Exemptions and Advice. Available online at: https://www.canada. $\mathrm{ca} / \mathrm{en} /$ public-health/services/diseases/2019-novel-coronavirus-infection/ latest-travel-health-advice.html (accessed August 21, 2020).

Government of Canada (2020g). Pathway to Permanent Residency Recognizes Exceptional Service of Asylum Claimants on Front Lines of COVID-19 Pandemic. Available online at: https://www.canada.ca/en/immigrationrefugees-citizenship/news/2020/08/pathway-to-permanent-residencyrecognizes-exceptional-service- of-asylum-claimants-on-front-lines-ofcovid-19-pandemic.html (accessed September 15, 2020).

Government of Canada (2020h). Study Permit: Covid-19 Program Delivery. Available online at: https://www.canada.ca/en/immigration-refugeescitizenship/corporate/publications-manuals/operational-bulletins-manuals/ service-delivery/coronavirus/temporary-residence/study-permit.html\#sec1.3 (accessed November 15, 2020).

Government of Canada (2020i). Government of Canada Announces Plan to Support Economic Recovery Through Immigration. Available online at: https://www.canada.ca/en/immigration-refugees-citizenship/news/2020/10/ 
government-of-canada-announces-plan-to-support-economic-recoverythrough-immigration.html (accessed November 15, 2020).

Gruda, A. (2020). Demandeurs d'asile: Remercier à Reculons. La Presse. 18 August 2020. Available online at: https://www.lapresse.ca/debats/editoriaux/ 2020-08-18/demandeurs-d-asile-remercier-a- reculons.php (accessed September 15, 2020).

Guttmann, A., Gandhi, S., Wanigaratne, S., Lu, H., Ferreira-Legere, L. E., Paul, J., et al. (2020). COVID-19 in Immigrants, Refugees and Other Newcomers in Ontario: Characteristics of Those Tested and Those Confirmed Positive, as of June 13, 2020. ICES: Toronto, ON.

Harris, S. (2020). 'Canadian-American couple reunited after compiling 250-page binder proving common-law status.' CBC News. 17 July 2020. Available online at: https://www.cbc.ca/news/business/cbsa-canada-u-s-border-restrictionscommon-law-couple- 1.5651128 (accessed November 16, 2020).

Hennebry, J. L., Caxaj, C. S., McLaughlin, J., and Mayell, S. (2020). Coronavirus: Canada stigmatizes, jeopardizes essential migrant workers. The Conversation. Available online at: https://theconversation.com/amp/coronavirus-canadastigmatizes-jeopardizes-essential-migrant-workers-138879 (accessed August 21, 2020).

Kestler-D’Amours, J. (2020). "Why not us?”: Asylum seekers on COVID-19 front lines demand permanent residency in Canada. Toronto Star. 15 August 2020. Available online at: https://www.thestar.com/news/canada/2020/08/15/ why-not-us-asylum-seekers-on-covid-19-front-lines-demand-permanentresidency.html (accessed September 15, 2020).

Mégret, F. (2020, March 30). COVID-19 Symposium: Returning "Home"Nationalist International Law in the Time of the Coronavirus. OpinioJuris. Available online at: http://opiniojuris.org/2020/03/30/covid-19-symposiumreturning-home-nationalist-international-law-in-the-time-of-thecoronavirus/ (accessed August 21, 2020).

Migrant Workers Alliance for Change (2020). Unheeded Warnings: COVID-19 \& Migrant Workers in Canada. Available online at: https://migrantworkersalliance.org/wp-content/uploads/2020/06/

Unheeded-Warnings-COVID19-and-Migrant-Workers.pdf (accessed November 15, 2020).

Mohammed, J. (2020). If Canada can welcome the NHL, it can welcome refugees. Toronto Star. 4 August 2020. Available online at: https://www.thestar.com/ opinion/contributors/2020/08/04/if-canada-can-welcome-the-nhl-it-canwelcome-refugees.html (accessed 10 September 2020).

Mojtehedzadeh, S. (2020, April 13). Migrant farm workers from Jamaica are being forced to sign COVID- 19 waivers. Toronto Star. Available online at: https:// www.thestar.com/business/2020/04/13/migrant-farm-workers-fear-exposureto-covid-19.html (accessed August 21, 2020).
Muggeridge, P. (2020, October 15). Trudeau urges snowbirds not to fly south this winter. Zoomer. Available online at: https://www.everythingzoomer. com/travel/2020/10/15/trudeau-urges-snowbirds-not-to-fly-south/ (accessed November 15, 2020).

Pilon-Larose, H. (2020, November 10). Québec ouvre la porte à élargir son programme. La Presse. Available online at: https://www.lapresse.ca/actualites/ 2020-11-10/regularisation-du-statut-des-anges-gardiens/quebec-ouvre-laporte-a-elargir-son-programme.php (accessed November 12, 2020).

Purohit, K., and Mukherjee, T. (2020, March 24). Foreign tourists face hostility in India amid coronavirus panic. Aljazeera. Available online at: https:// www.aljazeera.com/news/2020/03/foreign-tourists-face-hostility-indiacoronavirus-panic-200324083648362.html (accessed August 21, 2020).

Rehaag, S. (2020). 'Whose Travel is Essential During COVID-19: Hockey Players or Asylum Seekers?' The Conversation. 17 June 2020. Available online at: https://theconversation.com/whose-travel-is-essential-during-coronavirushockey-players-or-asylum-seekers- 140239 (accessed September 10, 2020).

Salter, M. (2012). Theory of the / : the suture and critical border studies. Geopolitics 17, 734-755. doi: 10.1080/14650045.2012.660580

Statistics Canada (2020). Canadian and International Tuition Fees by Level of Study. Available online at: https://www150.statcan.gc.ca/t1/tbl1/en/tv.action? pid=3710004501 (accessed August 21, 2020).

Stevens, M. (2020, March 29). How Asian-American leaders are grappling with xenophobia amid coronavirus. The New York Times. Available online at: https:// www.nytimes.com/2020/03/29/us/politics/coronavirus-asian-americans.html? searchResultPosition=1 (accessed August 21, 2020).

Taylor (2020). Taylor v. Newfoundland and Labrador, 2020 NSLC 125

United Nations High Commissioner for Refugees (2020). Key Legal Considerations on Access to Territory for Persons in Need of International Protection in the Context of the COVID-19 Response. Available online at: https://www.refworld. org/docid/5e7132834.html (accessed March 16, 2020).

Walzer, M. (1982). Spheres of Justice. Boston, MA: Basic Books.

Conflict of Interest: The author declares that the research was conducted in the absence of any commercial or financial relationships that could be construed as a potential conflict of interest.

Copyright (C) 2020 Macklin. This is an open-access article distributed under the terms of the Creative Commons Attribution License (CC BY). The use, distribution or reproduction in other forums is permitted, provided the original author $(s)$ and the copyright owner(s) are credited and that the original publication in this journal is cited, in accordance with accepted academic practice. No use, distribution or reproduction is permitted which does not comply with these terms. 